\title{
Inventarisasi Ektoparasit Protozoa Dan Arthropoda Yang Menginfestasi Ikan Air Tawar Di Kota Banyuwangi, Jawa Timur
}

\section{Inventarisation of Protozoan and Arthropoda Ectoparasitic Infestation in Freshwater Fish in Banyuwangi City, East Java}

\author{
Mohammad Faizal Ulkhaq ${ }^{1 *}$, Darmawan Setia Budi ${ }^{1}$, Kismiyati $^{2}$ \\ ${ }^{1}$ Prodi Budidaya Perairan PSDKU UNAIR di Banyuwangi, Jl. Wijayakusuma 113, Banyuwangi. \\ ${ }^{2}$ Fakultas Perikanan dan Kelautan, Universitas Airlangga, Jl. Mulyorejo Kampus C Surabaya \\ Email: m-faizalulkhaq@fpk.unair.ac.id
}

\begin{abstract}
Abstrak
Kerugian yang ditimbulkan akibat infestasi ektoparasit memang tidak sebesar kerugian yang diakibatkan oleh infeksi organisme lain seperti virus dan bakteri, namun infeksi ektoparasit dapat menjadi salah satu faktor predisposisi bagi infeksi organisme pathogen yang lebih berbahaya yang mengakibatkan kematian pada ikan. Penelitian ini bertujuan untuk menginventarisasi ektoparasit yang menginfestasi ikan air tawar yang dibudidayakan di beberapa kecamatan di Kota Banyuwangi yang hasilnya diharapkan dapat dijadikan acuan dalam upaya mencegah penyebaran penyakit pada ikan budidaya. Sampel penelitian berupa ikan nila, ikan mas dan ikan lele yang diperoleh dari enam kecamatan di Kota Banyuwangi, yaitu Kecamatan Kota, Kabat, Licin, Kalipuro, Giri, dan Glagah. Metode pemeriksaan ektoparasit dilakukan secara natif dengan mengerok permukaan tubuh, sirip dan insang ikan, lalu diamati dibawah mikroskop dengan perbesaran mulai 40-400x. Hasil pengamatan selanjutnya didokumentasikan dan diidentifikasi menurut kunci identifikasi. Ektoparasit yang ditemukan menginfestasi ikan air tawar di Kota Banyuwangi terdiri dari 4 genus yaitu Argulus, Lernaea, Chonopeltis dan Trichodina. Perlu dilakukan penelitian lebih lanjut untuk mengetahui prevalensi dan intensitas ektoparasit dalam rangka mencegah penyebaran ektoparasit di wilayah lain.
\end{abstract}

Kata Kunci : Inventarisasi, ektoparasit, ikan air tawar, Banyuwangi

\begin{abstract}
Detriment caused by ectoparasitic infestation was not as big detriment caused by infestation of other organisms such as viruses and bacteria, but it could be a predisposing factor for the infection of more dangerous pathogenic in fish. The aims of this study was to inventory ectoparasites that infecting freshwater fish cultivated in several districts in the Banyuwangi, in which the results were expected to be used as a reference in an effort to prevent the spread of disease in fish culture. The sample of research consisted of tilapia fish, carp and catfish which were obtained from six sub districts in Banyuwangi, those were Kota, Kabat, Licin, Kalipuro, Giri, and Glagah. The ectoparasite examination method was performed naturally by scraping the surface of the body, fins and gills of the fish, then observed under a microscope with magnification ranging from 40 to 400x. The results of further observations were documented and identified by key identification. Ectoparasites which were found infesting freshwater fish in the city of Banyuwangi consisted of 4 genuses: namely Argulus, Lernaea, Chonopeltis and Trichodina. Further research is needed to determine the prevalence and intensity of ectoparasites in order to prevent the spread of ectoparasites in other regions.
\end{abstract}

Keywords: Inventarisation, ectoparasites, freshwater fish, Banyuwangi 
Journal of Aquaculture Science

DOI: https://doi.org/10.31093/joas.v3i1.36
April 2018 vol 3 (1): 9-16

Online pada http://joas.co.id

\section{PENDAHULUAN}

Potensi budidaya ikan air tawar di Kabupaten Banyuwangi pada tahun 2016 mencapai 4200 ton dengan nilai produksi 24,5 juta rupiah. Jenis ikan air tawar yang diunggulkan yaitu ikan lele, ikan mas dan ikan nila (Pemkab Banyuwangi, 2016). Tingginya potensi budidaya ikan air tawar di Banyuwangi tidak terlepas dari masalah penyakit. Penyakit merupakan masalah utama yang sering dihadapi dalam budidaya yang dapat menyebabkan menurunnya tingkat produksi ikan. Terjadinya suatu penyakit karena interaksi yang tidak serasi antara ikan dengan kondisi kolam akan menyebabkan ikan mengalami stress sehingga mekanisme pertahanan diri yang dimilikinya menjadi lemah dan akhirnya mudah terserang penyakit. Parasit merupakan penyakit ikan yang sering menginfeksi ikan budidaya. (Sarjito dkk., 2013). Berdasarkan habitatnya, parasit digolongkan menjadi ektoparasit yang menginfestasi permukaan tubuh ikan dan endoparasit yang menginfeksi organ dalam tubuh ikan. Ektoparasit pada ikan didominasi oleh spesies dari filum Arthropoda,
Protozoa dan Helmint, sedangkan golongan Helmint mendominasi endoparasit pada ikan (Kabata, 1985).

Serangan parasit membuat ikan kehilangan nafsu makan, kemudian perlahan-lahan lemas dan berujung kematian Sinderman (1990). Kerugian non lethal lain dapat berupa kerusakan organ yaitu kulit dan insang, pertumbuhan lambat dan penurunan nilai jual. Lebih lanjut, Hidayati dkk (2016) menambahkan keberadaan parasit pada ikan akan berdampak pada pengurangan konsumsi, penurunan kualitas pada usaha budidaya, penurunan bobot badan ikan konsumsi dan penolakan oleh konsumen akibat bentuk ikan yang abnormal. Khusus ektoparasit, kerugian yang ditimbulkan akibat infestasi ektoparasit memang tidak sebesar kerugian yang diakibatkan oleh infeksi organisme lain seperti virus dan bakteri, namun infeksi ektoparasit dapat menjadi salah satu faktor predisposisi bagi infeksi organisme pathogen yang lebih berbahaya (Rahayu, 1986).

Penelitian mengenai inventarisasi ektoparasit telah banyak 
Journal of Aquaculture Science

DOI: https://doi.org/10.31093/joas.v3i1.36
April 2018 vol 3 (1): 9-16

Online pada http://joas.co.id dilakukan di daerah lain. Hasil penelitian Islami dkk melaporkan bahwa jenis ektoparasit yang ditemukan menginfestasi ikan patin (Pangasius hypophthalmus) di Sungai Kelakar terdiri dari Dactylogyrus sp., Ichtyophthirius multifiliis, dan Trichodina sp.. Winaruddin dan Eliawardani (2007) menyatakan bahwa ikan mas yang dibudidayakan dalam keramba jaring apung di Danau Laut Tawar Kabupaten Aceh Tengah terinfestasi ektoparasit jenis Trichodina sp., Ichtyophthirius multifiliis, Dactylogyrus sp., Gyrodactylus sp., Epistylis sp. dan Lernaea sp.. Hasil penelitian lain menyebutkan bahwa ikan air tawar yang dibudidayakan di Unit Perikanan Rakyat (UPR) Kelurahan Bungus Timur, Kota Padang terinfestasi ektoparasit jenis Dactylogyrus sp. dan Argulus foliaceus (Ramayulis dkk., 2014). Informasi mengenai inventarisasi ektoparasit pada ikan air tawar di Kota Banyuwangi masih belum ada, sehingga penelitian ini bertujuan untuk menginventarisasi ektoparasit yang menginfestasi ikan air tawar yang dibudidayakan di beberapa kecamatan di Kota Banyuwangi.
Data hasil penelitian ini diharapkan dapat dijadikan acuan dalam upaya mencegah penyebaran penyakit pada ikan budidaya dalam upaya menurunkan tingkat kematian pada ikan yang dapat merugikan para pembudidaya.

\section{MATERI DAN METODE}

Penelitian ini dilaksanakan pada bulan Februari-Juni 2018 di Laboratorium Anatomi Program Studi Di luar Kampus Utama (PSDKU) Universitas Airlangga di Banyuwangi. Sampel penelitian berupa ikan mas (Cyprinus carpio), ikan nila (Oreochromis niloticus) dan ikan lele (Clarias gariepinus) yang diperoleh dari pembudidaya di Kecamatan Kota, Kecamatan Kabat, Kecamatan Licin, Kecamatan Kalipuro, Kecamatan Giri dan Kecamatan Glagah. Metode penelitian ini menggunakan survei dan lokasi pengambilan sampel ditentukan dengan sengaja (purposive sampling).

Pemeriksaan ektoparasit dilakukan dengan metode natif dengan melakukan pengerokan (scrapping) pada permukaan tubuh, sirip dan insang. Sebelum dilakukan 
pemeriksaan, ikan dimatikan terlebih dahulu dengan jarum. Pemeriksaan ektoparasit protozoa dilakukan dengan cara mengerok lendir yang terdapat pada permukaan tubuh dengan menggunakan scalpel dan diletakkan diatas gelas objek, ditetesi dengan air 2-3 tetes dan aditutup menggunakan kaca penutup, diamati dibawah mikroskop dengan perbesaran 100x dan 400x. Pemeriksaan ektoparasit arthropoda dilakukan dengan mengamati ektoparasit langsung dalam tubuh ikan, karena ektoparasitnya berukuran besar dan terlihat menempel pada inang. Ektoparasit arthopoda diambil menggunakan pinset dan diamati dibawah mikroskop dengan perbesaran 40x dan $100 x$

Hasil pemeriksaan ektoparasit kemudian difoto dan dicocokkan dengan buku identifikasi. Ektoparasit protozoa diidentifikasi langsung pada saat menemukan ektoparasit, sedangkan ektoparasit arthropoda, sebelum diidentifikasi harus dilakukan pewarnaan terlebih dulu dengan metode Semichen AceticCarmin (Kuhlman, 2009). Hasil identifikasi selanjutnya dicocokkan bentuk morfologinya dengan buku identifikasi yaitu Woo (2006) dan Kabata (1985).

\section{HASIL DAN PEMBAHASAN}

Hasil penelitian menunjukkan bahwa ikan air tawar yang dibudidayakan di enam kecamatan di Kota Banyuwangi terinfestasi ektoparasit jenis Argulus sp., Lernaea sp., Trichodina sp., Chonopeltis sp. seperti tertera pada tabel 1.

Tabel 1. Jenis Ektoparasit yang Menginfestasi Ikan Air Tawar di Enam Kecamatan di Kota Banyuwangi

\begin{tabular}{lcccccc}
\hline \multicolumn{1}{c}{ Kecamatan } & Argulus & \multicolumn{2}{c}{ Senis Ektoparasit yang ditemukan } & \\
& Lernaea & Trichodina & Chonopeltis \\
\hline Kota & $\sqrt{ }$ & $\sqrt{ }$ & $\sqrt{ }$ & - \\
Kabat & $\sqrt{ }$ & $\sqrt{ }$ & $\sqrt{ }$ & $\sqrt{ }$ \\
Licin & $\sqrt{ }$ & $\sqrt{ }$ & $\sqrt{ }$ & $\sqrt{ }$ \\
Kalipuro & $\sqrt{ }$ & & $\sqrt{ }$ & $\sqrt{ }$ & - \\
Giri & $\sqrt{ }$ & & $\sqrt{ }$ & - & - \\
Glagah & & & ektoparasit dari golongan Arthopoda \\
\multicolumn{1}{c}{ Berdasarkan } & & hasil & (Argulus & sp., & Lernaea & sp., \\
pengamatan ditemukan & 3 & jenis & Chonopeltis & sp.) & dan & jenis
\end{tabular}


ektoparasit Protozoa (Trichodina sp.). Hasil ini sejalan dengan hasil penelitian lain yang dilakukan oleh Ulkhaq dkk. (2017) yang menyatakan bahwa ikan mas (Cyprinus carpio) yang dibudidayakan di Balai Benih Ikan Kabat Banyuwangi terinfestasi Zoothamnium sp., Trichodina sp., Oodinium sp. Vorticella sp., Argulus sp., Lernaea sp., Dactylogyrus sp., dan Gyrodactylus sp. dengan predileksi di kulit, sirip, dan insang.

Ektoparasit Argulus dan Lernaea ditemukan pada semua kecamatan tempat pengambilan sampel. Hal ini menunjukkan bahwa kedua jenis ektoparasit ini memiliki penyebaran yang luas dan tergolong ektoparasit utama yang menginfestasi ikan air tawar. Sumiati dan Aryati (2010) menegaskan bahwa jenis parasit yang umum ditemukan pada ikan hias air tawar adalah kelompok Monogenoida (Dactylogyrus sp., Gyrodactylus sp.), Chiliopora (Trichodina sp., Ichtyopphthirius multifiliis, Chilodonella sp.), Crustacea (Lernaea cyprinacea, Argulus sp.). Iyaji and Eyo (2008) menjelaskan bahwa ikan air tawar merupakan inang yang cocok untuk perkembangan parasit Argulus, Lernaea, dan Ergasillus.

Argulus sp. merupakan ektoparasit Arthropoda yang berbentuk oval, berwarna putih krem dan menempel di kulit dan sirip ikan. Penempelan Argulus pada tubuh ikan menggunakan sepasang alat penghisap (sucker) yang terdapat pada bagian cephalothorax (Kabata, 1985). Ikan yang terinfestasi Argulus menunjukkan gejala klinis berupa produksi mucus yang berlebih, ikan menggesekkan tubuhnya ke substrat, inflamasi dan pendarahan (AlvarezPellitero et al., 2004). Lebih lanjut Alberg et al., (2016) menyebutkan bahwa luka dan pendarahan yang muncul karena infestasi Argulus dapat memicu infeksi sekunder karena patogen lain sehingga menyebabkan kematian pada ikan.

Lernaea sp. termasuk dalam ektoparasit Arthropoda yang berbentuk panjang seperti jarum dan memiliki alat penempel berupa jangkar (Holdfast) yang terdapat pada bagian anterior. Holdfast ini merupakan salah satu bagian yang membedakan antar spesies dari genus Lernaea (Hossain et al., 2018). 
Lernaea yang menginfestasi ikan akan menyebabkan terjadinya pendarahan, luka, kesulitan bernafas, dan anemia (Mlaganau and Gatu, 2016). Marquardt et al. (2000), menambahkan kematian pada ikan yang terinfestasi Lernaea dapat disebabkan oleh infeksi patogen lain yang masuk melalui luka terbuka yang dihasilkan.

Secara makroskopis, ektoparasit Argulus dan Chonopeltis memiliki bentuk yang mirip, namun jika diamati lebih lanjut dibawah mikroskop terdapat perbedaan besarnya cephalothorax. Cephalothorax yang dimiliki Argulus lebih besar dibandingkan cephalothorax Chonopeltis (Mlaganau and Gatu, 2016). Lebih lanjut Abowei and Ezekiel (2011) menerangkan bahwa Chonopeltis memiliki ukuran yang lebih kecil, tidak memiliki lubang mulut tetapi digantikan oleh bentuk alat penghisap yang lebih berkembang serta tidak dapat berenang untuk mencari inang yang baru. Secara umum, kerugian yang ditimbulkan oleh infestasi Chonopeltis sama dengan ektoparasit arthropoda lain yaitu timbulnya luka, perdarahan, gangguan pertumbuhan dan reproduksi hingga kematian akibat infeksi sekunder oleh patogen lain (Fontana et al., 2012).

Trichodina sp. merupakan satu-satunya ektoparasit Protozoa yang ditemukan dalam penelitian ini. Trichodina memiliki bentuk menyerupai lonceng, namun jika diamati dibawah mikroskop terlihat berbentuk lingkaran menyerupai roda yang dikelilingi oleh denticle. Smith and Schwarz (2009) menyebutkan bahwa ektoparasit Trichodina berbentuk oval, pipih dorsoventral yang menginfestasi ikan air tawar dan laut. Karakteristik ektoparasit Trichodina yaitu memiliki dentikular yang menyerupai gigi yang digunakan untuk menempel pada inangnya. Ikan yang terinfestasi Trichodina menunjukkan gejala klinis pada infestasi berat yaitu sisik mengelupas dan rontok, perubahan warna tubuh (lebih gelap/pucat), pendarahan, timbul bercak luka, tubuh kurus dan gangguan renang (Khosnood and Khosnood, 2014). Kerugian yang ditimbulkan karena infestasi Trichodina sp. pada ikan yaitu gangguan pertumbuhan dan kerusakan insang yang dapat 
Journal of Aquaculture Science

DOI: https://doi.org/10.31093/joas.v3i1.36
April 2018 vol 3 (1): 9-16

Online pada http://joas.co.id mengakibatkan kematian pada ikan

(Madsen et al., 2000; Raissy and

Ansari, 2011).

\section{KESIMPULAN DAN SARAN}

Ektoparasit yang ditemukan menginfestasi ikan air tawar di Kota Banyuwangi terdiri dari 4 genus yaitu Argulus, Lernaea, Chonopeltis dan Trichodina. Perlu dilakukan penelitian lebih lanjut untuk mengetahui prevalensi dan intensitas ektoparasit dalam rangka mencegah penyebaran ektoparasit di wilayah lain.

\section{DAFTAR PUSTAKA}

Aalberg, K., Koscova, L., Smiga, L., Kosuth, P., Kosco, J., Oros, M., Barcak, D., P. Lazar. 2016. A Study of fish Lice (Argulus sp.) Infection in Freshwater Food Fish. Folia Veterinaria 60(3): 54-59.

Abowei, J.F.N., E.N. Ezekiel. 2011. A Review of Acanthocephala, Leeches, Parasites Crustaceans and Some Other Parasites of Miscellaneous Taxa Infections in African Fish. International Journal of Animal and Veterinary Advances 3(5): 337-351.

Alvarez-Pellitero, P., Barja, J.L., Basurco, B., Berthe, F., A.E. Toranzo. 2004. Meditterranean Aquaculture Diagnostic Laboratories. Zaragoza: CIHEAM. p.103-130.

Fontana, M., Takemoto, R.A., Malta, J.C.O., and L.A.F. Mateus. 2012. Parasitism by Argulids (Crustacea-Branchiura) in Piranha (Osteichtyes: Serrasalmidae) Captured in the Caicara Bays, Upper Paraguay River, Pantanal, Mato Grosso State, Brazil. Neotropical Ichtyology 10(3): 653659.
Hidayati, N., Bakri, M., Rusli, Fahrimal, Y., Hambal, M., R. Daud. 2016. Identifikasi Parasit pada Ikan Tongkol (Euthynnus affinis) di Tempat Pelelangan Ikan Lhoknga Aceh Besar. Jurnal Media Veterinaria 10(1): 5-8.

Hossain, M., Ferdoushi, J., A.H. Rupon. 2018. Biology of Anchor Worms (Lernaea cyprinacea). Journal of Entomology and Zoology Studies 6(1): 910-917.

Islami, H., Prayogo, S., Triyanto. 2017. Inventarisasi Ektoparasit pada Ikan Patin (Pangasius hypophtalmus) yang Diberi Pakan Day Old Chick di Sungai Kelaekar Desa Segayam. Jurnal Ilmu-Ilmu Perikanan dan Budidaya Perairan 12(2): 58-65.

Iyaji, F.O., and J.E. Eyo. 2008. Parasites and Their Freshwater Fish Host. BioResearch 6(1): 328-338.

Kabata, Z. (1985). Parasites and Diseases of Fish Cultured in The Tropics. Taylor and Francis. London and Philadelphia. 318 p.

Khoshnood, Z., and R. Khoshnood. 2014. Histopathological Effect of Trichodiniasis in Farmed Rainbow Trout, Oncorhynchus mykiss in West of Iran. International Journal of Animal and Veterinary Sciences 8(10): 1154-1157.

Kuhlmann, W.F. 2006. Preservation, Staining, and Mounting Parasite Spesiment. http://www.facstaff.unca.com. 8p.

Madsen, H.C.K., Buchmann, K., S. Mellergaard. 2000. Trichodina sp. (Ciliophora: Peritrichida) in Eel Anguilla anguilla in Recirculation Systems in Denmark: Host-Parasites Relations. Disease of Aquatic Organism 42: 140-152.

Marquardt, W.C., Demaree, R.S., B. Grieve. 2000. Parasitology and Vector Biology. 2nd edition. USA: HAP pp: 527-534.

Mlaganau, K., and A. Gatu. 2016. Review on Major Parasitic Crustacean in Fish. Fisheries and Aquaculture Journal 7(3): 5p.

Pemerintah Kabupaten Banyuwangi. 2016. Laporan Keterangan Pertanggung jawaban Bupati Banyuwangi Akhir Tahun Anggaran. 601 hal. 
Rahayu, A. 1986. Penyakit-penyakit Pada Ikan-ikan Laut. Oseana 11(3): 101110.

Raissy, M., and M. Ansari. 2011. Histopathological Changes in the Gills of Naturally-Infected Capoeta aculeata (Cuvier and Valenciennes, 1844) with Parasites. African Journal of Biotechnology 10(68): 1542215425.

Ramayulis, Muhar, N., L. Deswanti. 2014. Inventarisasi Ektoparasit pada Beberapa Jenis Ikan di Unit Perikanan Rakyat (UPR) Kelurahan Bungus Timur, Kota Padang. Fakultas Perikanan dan Ilmu Kelautan Universitas Bung Hatta Padang. 10 hal.

Sarjito, Prayitno, S.B., A.H.C.Haditomo. 2013. Buku Pengantar Parasit dan Penyakit Ikan. Fakultas Perikanan dan Ilmu Kelautan. Universitas Diponegoro.

Sindermann, C.J. 1990. Principle Disease of Marine Fish and Shellfish. 2nd ed. Vol 1. Academic Press, Inc. San Diego, California.

Smith, S., and M. Schwarz. 2009. Dealing with Trichodina and Trichodina-like Species. Commercial Fish and Shellfish Technology Fact Sheet. Virginia Cooperative Extension. Publication 600-200. 3p.

Sumiati, T., dan Y. Aryati. 2010. Penyakit Parasitik pada Ikan Hias Air Tawar. Prosiding Forum Inovasi Teknologi Akuakultur 2010. 963-967.

Ulkhaq, M.F., Budi, D.S., Mahasri, G., Kismiyati. 2017. Identifikasi Ektoparasit pada Benih Ikan Mas (Cyprinus carpio) di Balai Benih Ikan Kabat, Kabupaten Banyuwangi. Jurnal Sains Veteriner 35(2): inpress.

Winaruddin dan Eliawardani. 2007. Inventarisasi Ektoparasit yang Menyerang Ikan Mas yang Dibudidayakan dalam Jaring Apung di Danau Laut Tawar Kabupaten Aceh Tengah. Jurnal Kedokteran Hewan 1(2): 66-69.

Woo, PTK. (2006). Fish disease and disorders, Volume 1: Protozoan and metazoan infections $2^{\text {nd }} \mathrm{Ed}$. CABI International. Cambridge, USA. 801 p. 